\title{
Reduced Nutrient Excretion and Environmental Microbial Load with the Addition of a Combination of Enzymes and Direct-Fed Microbials to the Diet of Broiler Chickens
}

\section{-Author(s)}

\author{
Praes MFFM' \\ Lucas Junior J" \\ Duarte KF"II \\ Sorbara JOB \\ Matos Junior JB"I \\ Sgavioli S ${ }^{\vee}$ \\ Domingues $\mathrm{CHF}^{\mathrm{V}}$ \\ Garcia RG ${ }^{\vee}$ \\ Hermes RGIv
}

Department of Nutrition and Animal Production, São Paulo State University, 13.635900, Pirassununga-SP, Brazil.

" Department of Agricultural Engineering, São Paulo State University, 14884-900, Jaboticabal-SP, Brazil.

III Department of Morphology and Animal Physiology, São Paulo State University, 14884-900, Jaboticabal-SP, Brazil.

iv DSM Nutritional Products, 05321-010, São Paulo, São Paulo, Brazil.

$\checkmark$ Federal University of Grande Dourados, College of Agricultural Sciences, 79.804970, Dourados-MS, Brazil.

\section{nail Address}

Corresponding author e-mail address Maria Fernanda Ferreira Menegucci Praes Department of Nutrition and Animal Production, São Paulo State University, Pirassununga - Avenida Duque de Caxias, 225, CEP: 13.635-900, Pirassununga, SP, Brazil.

Phone: +55 16991031540

E-mail: menegucci2002@yahoo.com.br

\section{-Keywords}

Waste ratio, total and thermotolerant coliforms, phosphorus, nitrogen, potassium.

\section{ABSTRACT}

This study evaluated the effects of the dietary inclusion of an enzyme blend and a direct-fed microbials in broiler diets on litter production and quality. In total, 900 Cobb $500^{\circledR}$ broiler chicks were distributed according to a completely randomized design into 4 treatments and 9 replicates of 25 birds each. Broilers were reared from 1 to 42 days of age. The treatments consisted of the following diets: NC: negative control; DFM: NC + 500 ppm of direct-fed microbials product (DFM), containing Bacillus subtilis and Bacillus licheniformis; ENZ: diet formulated with an enzyme blend (20 ppm phytase, 200 ppm protease and 200 ppm of xylanase); DFM+E: ENZ + DFM. Birds and litter were weighed at the start and end of the rearing period, for litter production and waste ratio (Rw) determination. Litter samples were analyzed for dry matter (DM) content, total and thermotolerant coliform counts, nutrient composition (nitrogen $(\mathrm{N})$, phosphorous $(\mathrm{P})$ and potassium $(\mathrm{K})$ ), and fiber fraction (neutral detergent fiber (NDF), acid detergent fiber (ADF) and lignin). The dietary inclusion of the evaluated additivesdid not influence litter production or Rw; however, ADF (\%), NDF ( $\mathrm{kg}$ and $\mathrm{kg} / \mathrm{kg}$ DM litter), and total and thermotolerant coliform counts were reduced, and $\mathrm{N}$ content increased in the litter. The diets containing enzymes (ENZ and $D F M+E$ ) reduced litter $P$ content. The addition of exogenous enzymes and their combination with a DFM based on Bacillus spp. Did not affect waste production, and reduced litter microbial load, and the contents of $\mathrm{P}$ and insoluble fiber in the litter.

\section{INTRODUCTION}

The poultry industry in Brazil has grown at a fast pace during recent decades. This progress is based not only on the number of chickens slaughtered or the number of eggs produced, but also in the production of high-quality protein at a low cost. Today, Brazil is globally the third producer, the second consumer market, and the first exporter of chicken meat (UBA, 2014). This accelerated growth has also generated high waste volumes, which disposal is a cause of concern both by the industry and the public. Studies have been recently conducted on novel methods to reduce the environmental impact of poultry industry, aiming at improving its sustainability.

Poultry litter is the substrate (wood shavings or chips, straw, bark, etc.) placed on the poultry house floor to absorb moisture and to provide comfort to the birds. At the end of the grow-out, the litter also contains bird excreta, feed residues, and feathers, and may be reused for the next flock or disposed as waste (Avila et al., 1992). The disposal of used litter in the environment, without previous treatment, can lead to serious problems related to the chemical and microbiological contamination of soil and water, as well as negatively 
Praes MFFM, Lucas Junior J, Duarte KF, Sorbara JOB, Matos Junior JB, Sgavioli S, Domingues CHF, Garcia RG, Hermes R
Reduced Nutrient Excretion and Environmental Microbial Load with the Addition of a Combination of Enzymes and Direct-Fed Microbials to the Diet of Broiler Chickens affect the quality of life of human populations living close to the production facilities.

Several factors influence the chemical composition of used litter, such as the composition of the feed supplied to the birds, litter substrate volume and type, season, bird density, ventilation, number of time the litter was reused, and excreta composition.

In order to improve the efficiency of nutrient utilization by the birds, a more precise feed formulation is necessary, increasing nutrient absorption by the birds, and reducing nutrient loss in the environment, thereby reducing the environmental impact of intensive animal production (Rondon, 2008). Among other approaches, the dietary addition of exogenous enzymes and agents that balance the intestinal microbiota may improve nutrient utilization, reducing excretion of pollutants in the environment (Ludke et al., 2002), and may also improve the microbiological quality of the environment by competitive exclusion. For instance, it was shown that broiler diets supplemented the enzyme phytase can lead to 25 to $35 \%$ reduction in dietary phosphorous content (Maguire et al., 2005). Also, supplementing broiler diets with a direct-fed microbial product based on Lactobacillus (Chang \& Chen, 2003) resulted in significant ammonia and odor reduction. However, few studies have been conducted aiming at assessing litter characteristics when these additives are used in broiler feeds.

Therefore, this study aimed at evaluating the effects of the dietary inclusion of an enzyme blend and a direct-fed microbials on poultry litter production and quality by including digestive additives and intestinal microbiota balancers in diets of broiler chickens from 1 to 42 days of age.

\section{MATERIALS AND METHODS}

In this experiment, 900 one-day-old Cobb $500 \AA$ broiler chicks, derived from a same breeder flock, distributed in an completely randomized experimental design with four treatments with nine replicates of 25 birds each. Birds were housed at a density of five birds/ $\mathrm{m}^{2}$. The experimental treatments were: $\mathrm{NC}$ : negative control; DFM: NC + 500 ppm of direct-fed microbials product (DFM), containing Bacillus subtilis and Bacillus licheniformis; ENZ: diet formulated with an enzyme blend (20 ppm of phytase, 200 ppm of protease and 200 ppm of xylanase enzymes activity); DFM+E: ENZ + DFM.

Litter substrate consisted of wood shavings at 0.7 $\mathrm{kg} \mathrm{DM} /$ bird housed, so that all treatment pens were covered with the same amount of litter (20 kgFM).
The chicks were vaccinated against Marek disease, infectious bursal disease (IBD), and fowl pox at the hatchery, followed by vaccination on the farm against IBD on $d 5$ and 21, and against Newcastle disease on d 7 , both via eye drop.

Environmental temperature and air relative humidity were daily recorded using digital thermometers placed at the birds' height. Curtains and fans were used to ensure thermal comfort of the birds. A lighting program of 24 hours of light was applied. The birds received water and feed ad libitum throughout the entire experimental period, which was divided into three rearing phases: starter (1 to 21 days of age), grower (22 to 35 days of age), and finisher (36 to 42 days of age).

In order to prevent litter contamination, considering the use of DFM in some treatments, surgical shoe covers were used by the workers during daily bird management.

Feed was based on corn and soybean meal, supplemented with minerals, vitamins, and amino acids, and formulated to meet the nutritional requirements of broilers according to rearing phase (starter, grower and finisher) following the recommendations of Rostagno et al. (2011) (Tables 1 and 2). Antibiotic growth promoters were not included in the feeds.

The nutritional matrix of each enzyme was taken into account for proper diet, considering that xylanase contributed with $40 \mathrm{kcal}$ metabolizable energy $\mathrm{kg}^{-1}$ of feed; phytase contributed with $0.15 \%$ available phosphorous and $0.12 \%$ calcium; and protease contributed with 3.8\% crude protein, 3.8\% digestible arginine, $1.2 \%$ digestible lysine, 3.6\% digestible methionine + cystine, $7.9 \%$ digestible threonine, and 3\% digestible tryptophan. The product used as DFM contained Bacillus subtilis (minimum $0.735 \times 10^{8}$ UFC $\mathrm{g}^{-1}$ ) and Bacillus licheniformis (minimum $0.735 \times$ $\left.10^{8} \mathrm{UFCg}^{-1}\right)$.

Litter was weighed (20 kg of litter per pen) at the beginning ( $d$ 1) and at the end of the grow-out ( $d 42$ ). Representative and significant litter samples (10\%) were collected at the end of the experiment for dry matter (DM) analysis, according to Silva \& Queiroz (2006). Litter DM content was used to calculate litter weight on DM $(\mathrm{kg})$ and on fresh matter $(\mathrm{FM})(\mathrm{kg})$ basis, per housed bird (kg DM/bird), and excreta weight per housed bird (EWB) (kg DM/bird). Waste ratio (RW) was calculated as the ratio between the amount of litter ( $\mathrm{kg} \mathrm{DM})$ and the live weight of chickens at the end of the rearing period ( $\mathrm{RW}=\mathrm{kg} \mathrm{DM}$ of poultry litter $/ \mathrm{kg}$ of live weight) (Strehler \& Sutzle, 1987) as an indication 
Praes MFFM, Lucas Junior J, Duarte KF, Sorbara JOB, Matos Junior JB, Sgavioli S, Domingues CHF, Garcia RG, Hermes R
Reduced Nutrient Excretion and Environmental Microbial Load with the Addition of a Combination of Enzymes and Direct-Fed Microbials to the Diet of Broiler Chickens

Table 01 - Ingredient composition of the experimental feeds fed during the starter, grower and finisher phases.

\begin{tabular}{lccccccccccccc}
\hline Ingredients (\%) & \multicolumn{4}{c}{ Starter } & \multicolumn{4}{c}{ Grower } & \multicolumn{4}{c}{ Finisher } \\
\hline Treatments* & NC & DFM & ENZ & DFM+E & NC & DFM & ENZ & DFM+E & NC & DFM & ENZ & DFM+E \\
\hline Corn & 50.36 & 50.36 & 55.04 & 55.04 & 58.23 & 58.23 & 62.90 & 62.90 & 62.95 & 62.95 & 67.54 & 67.54 \\
\hline Soybean meal & 40.80 & 40.80 & 38.30 & 38.30 & 32.60 & 32.60 & 30.10 & 30.10 & 28.60 & 28.60 & 26.30 & 26.30 \\
\hline Soybean oil & 4.70 & 4.70 & 3.10 & 3.10 & 4.80 & 4.80 & 3.20 & 3.20 & 4.60 & 4.60 & 2.90 & 2.90 \\
\hline Dicalcium phosphate & 1.86 & 1.86 & 1.05 & 1.05 & 1.90 & 1.90 & 1.09 & 1.09 & 1.75 & 1.75 & 0.94 & 0.94 \\
\hline Calcitic limestone & 1.24 & 1.24 & 1.43 & 1.43 & 1.26 & 1.26 & 1.46 & 1.46 & 0.97 & 0.97 & 1.16 & 1.16 \\
\hline Salt & 0.43 & 0.43 & 0.43 & 0.43 & 0.43 & 0.43 & 0.43 & 0.43 & 0.41 & 0.41 & 0.41 & 0.41 \\
\hline DL-Methionine 99\% & 0.22 & 0.22 & 0.20 & 0.20 & 0.21 & 0.21 & 0.20 & 0.20 & 0.18 & 0.18 & 0.16 & 0.16 \\
\hline L-Lysine HCl 78\% & 0.09 & 0.09 & 0.14 & 0.14 & 0.22 & 0.22 & 0.27 & 0.27 & 0.20 & 0.20 & 0.25 & 0.25 \\
\hline L-Threonine 98\% & 0.05 & 0.05 & 0.02 & 0.02 & 0.10 & 0.10 & 0.06 & 0.06 & 0.09 & 0.09 & 0.05 & 0.05 \\
\hline Enzymes** & 0.00 & 0.00 & 0.042 & 0.042 & 0.00 & 0.00 & 0.042 & 0.042 & 0.00 & 0.00 & 0.042 & 0.042 \\
\hline Probiotic & 0.00 & 0.05 & 0.00 & 0.05 & 0.00 & 0.05 & 0.00 & 0.05 & 0.00 & 0.05 & 0.00 & 0.05 \\
\hline Vit and min suppl. *** & 0.25 & 0.20 & 0.25 & 0.20 & 0.25 & 0.20 & 0.25 & 0.20 & 0.25 & 0.20 & 0.25 & 0.20 \\
\hline Total & 100.00 & 100.00 & 100.00 & 100.00 & 100.00 & 100.00 & 100.00 & 100.00 & 100.00 & 100.00 & 100.00 & 100.00 \\
\hline
\end{tabular}

*NC: negative control; DFM: NC + 500 ppm of direct-fed microbial product (DFM) containing Bacillus subtilis and Bacillus licheniformis; ENZ: diet formulated with an enzyme blend (20 ppm phytase enzyme, 200 ppm protease and 200 ppm de xylanase); DFM+E: ENZ + DFM. ${ }^{* *}$ Enriched vitamin and mineral supplement per kgof feed: $8, .000$ IU vitamin A, 1,800 IU vitamin D3, 12 mg vitamin E, 2 mg vitamin K3, 1 mg vitamin B1, 4 mg vitamin B2, $1 \mathrm{mg}$ vitamin B6, $10 \mu \mathrm{g}$ vitamin B12, $0.40 \mathrm{mg}$ folic acid, $0.04 \mathrm{mg}$ biotin, $28 \mathrm{mg}$ niacin, $11 \mathrm{mg}$ calcium pantothenate, $6 \mathrm{mg} \mathrm{Cu}, 0.10 \mathrm{mg} \mathrm{Co,} 1 \mathrm{mg} \mathrm{l,} 50 \mathrm{mg} \mathrm{Fe}, 65 \mathrm{mg} \mathrm{Mn}, 45 \mathrm{mg} \mathrm{Zn,} 0.21 \mathrm{mg} \mathrm{Se}, 500$ mg choline chloride $50 \%$, 12 mg antioxidant and coccidiostatic agent (salinomycin).

Table 02 - Calculated nutritional levels of the experimental feeds.

\begin{tabular}{|c|c|c|c|c|c|c|c|c|c|c|c|c|}
\hline \multirow{2}{*}{$\begin{array}{l}\text { Phases } \\
\text { Treatments* }\end{array}$} & \multicolumn{4}{|c|}{ Starter } & \multicolumn{4}{|c|}{ Grower } & \multicolumn{4}{|c|}{ Finisher } \\
\hline & NC & DFM & ENZ & $\mathrm{DFM}+\mathrm{E}$ & NC & DFM & ENZ & $\mathrm{DFM}+\mathrm{E}$ & NC & DFM & ENZ & $\mathrm{DFM}+\mathrm{E}$ \\
\hline Metabolizable Energy (kcal/kg) & 3000 & 3000 & 2960 & 2960 & 3100 & 3100 & 3060 & 3060 & 3200 & 3200 & 3160 & 3160 \\
\hline Crude Protein (\%) & 23.00 & 23.00 & 22.13 & 22.13 & 20.00 & 20.00 & 19.24 & 19.24 & 18.50 & 18.50 & 17.80 & 17.80 \\
\hline Total Arginine (\%) & 1.57 & 1.57 & 1.49 & 1.49 & 1.32 & 1.32 & 1.25 & 1.25 & 1.20 & 1.20 & 1.14 & 1.14 \\
\hline Digestible Arginine (\%) & 1.45 & 1.45 & 1.44 & 1.44 & 1.22 & 1.22 & 1.21 & 1.21 & 1.11 & 1.11 & 1.10 & 1.10 \\
\hline Total Lysine (\%) & 1.37 & 1.37 & 1.38 & 1.38 & 1.25 & 1.25 & 1.26 & 1.26 & 1.14 & 1.14 & 1.15 & 1.15 \\
\hline Digestible Lysine (\%) & 1.25 & 1.25 & 1.25 & 1.25 & 1.15 & 1.15 & 1.15 & 1.15 & 1.04 & 1.04 & 1.05 & 1.05 \\
\hline Total Methionine (\%) & 0.60 & 0.60 & 0.60 & 0.60 & 0.56 & 0.56 & 0.56 & 0.56 & 0.51 & 0.51 & 0.51 & 0.51 \\
\hline Total Methionine + Cystine (\%) & 0.98 & 0.98 & 0.94 & 0.94 & 0.90 & 0.90 & 0.86 & 0.86 & 0.83 & 0.83 & 0.80 & 0.80 \\
\hline Digestible Methionine (\%) & 0.57 & 0.57 & 0.56 & 0.56 & 0.54 & 0.54 & 0.52 & 0.52 & 0.49 & 0.49 & 0.47 & 0.47 \\
\hline Digestible Methionine + Cystine (\%) & 0.89 & 0.89 & 0.89 & 0.89 & 0.82 & 0.82 & 0.82 & 0.82 & 0.75 & 0.75 & 0.75 & 0.75 \\
\hline Total Threonine (\%) & 0.93 & 0.93 & 0.82 & 0.82 & 0.85 & 0.85 & 0.75 & 0.75 & 0.78 & 0.69 & 0.75 & 0.69 \\
\hline Digestible Threonine (\%) & 0.80 & 0.80 & 0.80 & 0.80 & 0.74 & 0.74 & 0.74 & 0.74 & 0.68 & 0.68 & 0.68 & 0.68 \\
\hline Total Tryptophan (\%) & 0.28 & 0.28 & 0.27 & 0.27 & 0.24 & 0.24 & 0.22 & 0.22 & 0.21 & 0.21 & 0.20 & 0.20 \\
\hline Digestible Tryptophan (\%) & 0.24 & 0.24 & 0.24 & 0.24 & 0.20 & 0.20 & 0.20 & 0.20 & 0.18 & 0.18 & 0.18 & 0.18 \\
\hline Total Isoleucine (\%) & 0.98 & 0.98 & 0.94 & 0.94 & 0.83 & 0.83 & 0.79 & 0.79 & 0.76 & 0.76 & 0.75 & 0.75 \\
\hline Digestible Isoleucine (\%) & 0.78 & 0.78 & 0.78 & 0.78 & 0.67 & 0.67 & 0.66 & 0.66 & 0.61 & 0.61 & 0.61 & 0.61 \\
\hline Total Leucine (\%) & 4.02 & 4.02 & 4.18 & 4.18 & 4.14 & 4.14 & 4.30 & 4.30 & 4.24 & 4.24 & 4.55 & 4.55 \\
\hline Digestible Leucine (\%) & 3.57 & 3.57 & 3.72 & 3.72 & 3.71 & 3.71 & 3.87 & 3.87 & 3.82 & 3.82 & 3.98 & 3.98 \\
\hline Total Valine (\%) & 1.08 & 1.08 & 1.04 & 1.04 & 0.93 & 0.93 & 0.89 & 0.89 & 0.86 & 0.86 & 0.85 & 0.85 \\
\hline Digestible Valine (\%) & 0.93 & 0.93 & 0.94 & 0.94 & 0.80 & 0.80 & 0.81 & 0.81 & 0.74 & 0.74 & 0.75 & 0.75 \\
\hline Total Phenylalanine (\%) & 1.15 & 1.15 & 1.11 & 1.11 & 0.99 & 0.99 & 0.95 & 0.95 & 0.91 & 0.91 & 0.88 & 0.88 \\
\hline Digestible Phenylalanine (\%) & 1.04 & 1.04 & 1.00 & 1.00 & 0.90 & 0.90 & 0.86 & 0.86 & 0.83 & 0.83 & 0.80 & 0.80 \\
\hline Crude Fiber (\%) & 2.76 & 2.76 & 2.72 & 2.72 & 2.51 & 2.51 & 2.47 & 2.47 & 2.40 & 2.40 & 2.37 & 2.37 \\
\hline Calcium (\%) & 1.00 & 1.00 & 0.88 & 0.88 & 1.00 & 1.00 & 0.88 & 0.88 & 0.85 & 0.85 & 0.73 & 0.73 \\
\hline Total Phosphorous (\%) & 0.68 & 0.68 & 0.53 & 0.53 & 0.66 & 0.66 & 0.51 & 0.51 & 0.63 & 0.63 & 0.48 & 0.48 \\
\hline Available Phosphorus (\%) & 0.45 & 0.45 & 0.45 & 0.45 & 0.45 & 0.45 & 0.45 & 0.45 & 0.42 & 0.42 & 0.42 & 0.42 \\
\hline Sodium (\%) & 0.19 & 0.19 & 0.19 & 0.19 & 0.19 & 0.19 & 0.19 & 0.19 & 0.18 & 0.18 & 0.18 & 0.18 \\
\hline Chlorine (\%) & 0.32 & 0.32 & 0.33 & 0.33 & 0.35 & 0.35 & 0.36 & 0.36 & 0.33 & 0.33 & 0.34 & 0.34 \\
\hline Potassium (\%) & 1.07 & 1.07 & 1.03 & 1.03 & 0.91 & 0.91 & 0.86 & 0.86 & 0.83 & 0.83 & 0.79 & 0.79 \\
\hline Choline (\%) & 1.248 & 1.248 & 1.227 & 1.227 & 1.133 & 1.133 & 1.112 & 1.112 & 1.082 & 1.082 & & 1.064 \\
\hline
\end{tabular}

*NC: negative control; DFM: NC + 500 ppm of direct-fed microbial product (DFM) containing Bacillus subtilis and Bacillus licheniformis; ENZ: diet formulated with an enzyme blend (20 ppm phytase enzyme, 200 ppm protease and 200 ppm de xylanase); DFM+E: ENZ + DFM. 
Praes MFFM, Lucas Junior J, Duarte KF, Sorbara JOB, Matos Junior JB, Sgavioli S, Domingues CHF, Garcia RG, Hermes R
Reduced Nutrient Excretion and Environmental Microbial Load with the Addition of a Combination of Enzymes and Direct-Fed Microbials to the Diet of Broiler Chickens of the potential waste generation of the production system.

The collected litter samples were analyzed for nitrogen $(N)$, phosphorous $(P)$, and potassium (K) contents. Nitrogen $(\mathrm{N})$ content was determined using the methodology described by Silva \& Queiroz (2006). Phosphorous (P) levels were determined using the methodology described by Malavolta (1989), and potassium (K) levels were determined in an atomic absorption spectrophotometer. Neutral detergent fiber (NDF), acid detergent fiber (ADF), and lignin contents were determined using the methodologies proposed by the AOAC (2005).

The multi-tube technique described by APHA (2005) was used for the total and thermotolerant coliform enumeration. The litter was diluted in peptone water solution at1: 9, obtaining serial decimal dilutions of 10-1 to 10-9 (in duplicate). A $20 \mathrm{~g}$ sample of poultry litter was collected under aseptic conditions in a sterile container and homogenised in $180 \mathrm{~mL}$ of peptone water. Samples were diluted in lauryl sodium sulfate broth, according to APHA (2005). Tubes with poultry litter samples were incubated at $35{ }^{\circ} \mathrm{C}$ for 24 to 48 hours. Samples presenting gas production in the Durham tubes and / or blurred staining were considered positive for total coliforms.

In order to confirm the results of the previous test, tubes positive for total coliforms were seeded in green bile broth (2\%) and incubated at $35 \pm 1{ }^{\circ} \mathrm{C}$ for 48 hours. The presence of thermotolerant fecal coliforms was determined by seeding the positive samples for total coliforms in EC broth (specific medium for Escherichia coli, pathogenic enteric bacteria used as indicator for thermotolerant fecal coliforms, and incubation at 44.5 $\pm 0.2^{\circ} \mathrm{C}$ for $18-24$ hours. The samples presenting gas production after this period were considered positive. The density of total and fecal coliforms in the litter were expressed in MPN $100 \mathrm{~mL}-1$.

Data were analyzed using the GLM procedure of SAS $^{\circledR}$ software (SAS Institute, 2002). When statistical significance was detected, means were compared by Tukey's test at 5\% probability level.

\section{RESULTS AND DISCUSSION}

No significant differences ( $p>0.05$ ) among treatments were detected for used litter characteristics, considering total DM and FM, DM per bird, Rw, or EWB (Table 3). Birds fed the diets containing additives presented similar waste production when compared with those fed the control diet. Santos \& Lucas Jr.
(2003) obtained an average litter production of 2.19 $\mathrm{kg}$ (FM) per broiler, which is close to the averages found in the present study.

Table 03 - Reused litter on fresh matter (FM) and dry matter (DM) basis, and per bird on DM basis, waste ratio (Rw), and amount of excreta (on DM basis) per housed bird (EWB) for broiler chickens fed with an enzyme blend and direct-fed microbes (DFM).

\begin{tabular}{|c|c|c|c|c|c|c|}
\hline \multirow[b]{2}{*}{ Treatments* } & \multicolumn{4}{|c|}{ Litter production } & \multirow[b]{2}{*}{$\begin{array}{l}\text { Rw } \\
(\mathrm{kg} / \\
\mathrm{kg})\end{array}$} & \multirow[b]{2}{*}{$\begin{array}{c}\text { EWB } \\
\text { (kg/bird) }\end{array}$} \\
\hline & $\begin{array}{l}\mathrm{FM} \\
(\mathrm{kg})\end{array}$ & $\begin{array}{l}\mathrm{DM} \\
(\mathrm{kg})\end{array}$ & $\begin{array}{c}\text { FM } \\
\text { (kg/bird) }\end{array}$ & $\begin{array}{l}\mathrm{DM} \\
\text { (kg/ } \\
\text { bird) }\end{array}$ & & \\
\hline NC & 55.03 & 45.84 & 2.20 & 1.87 & 0.64 & 1.13 \\
\hline DFM & 53.90 & 44.53 & 2.15 & 1.82 & 0.66 & 1.08 \\
\hline ENZ & 55.95 & 44.84 & 2.24 & 1.81 & 0.65 & 1.10 \\
\hline $\mathrm{DFM}+\mathrm{E}$ & 55.22 & 45.02 & 2.21 & 1.83 & 0.67 & 1.11 \\
\hline F Values & 0.48 & 0.22 & 0.52 & 0.24 & 0.29 & 0.34 \\
\hline P Values & $0.69^{\text {NS }}$ & $0.88^{\mathrm{NS}}$ & $0.63^{\mathrm{NS}}$ & $0.86^{\mathrm{NS}}$ & $0.87^{\mathrm{NS}}$ & $0.79^{\text {NS }}$ \\
\hline $\mathrm{CV}^{1}(\%)$ & 6.68 & 7.89 & 7.82 & 6.45 & 0.83 & 10.45 \\
\hline
\end{tabular}

${ }^{1}$ Coefficient of variation; . ${ }^{*} \mathrm{NC}{ }^{*} \mathrm{NC}$ : negative control; DFM: NC +500 ppm of direct-fed microbial product (DFM) containing Bacillus subtilis and Bacillus licheniformis; ENZ: diet formulated with an enzyme blend (20 ppm phytase enzyme, 200 ppm protease

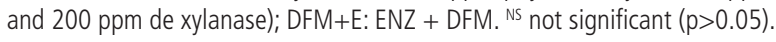

The moisture content results are consistent with the recommendations of Almeida (1986), to maintain litter moisture content between 20 and 35\%; however, at higher values, the litter becomes "damp" and "viscous". Damp litter does not provide comfort to the birds, and reduces weight gain, feed conversion ratio, and disease resistance.

The supplementation of poultry diets with exogenous enzymes and DFM may improve nutrient utilization, and consequently, reduce waste production, because the animal is able to digest plant ingredients more efficiently, thereby excreting a smaller amount of undigested matter. Pinheiro et al. (2008) obtained $10 \%$ reduction in waste production when adding an enzyme blend in the diet of broiler chickens. Santos (2010) also found lower waste production (5.3\%) when enzymes were added alone or in combination with a probiotic to broiler diets. When comparing waste production between the $1^{\text {st }}$ and the $2^{\text {nd }}$ broiler flock reared on the same litter, Santos (1997) observed accumulated waste was reduced in approximately $16 \%$ in reused litter. However, this effect was not observed in the present study.

There was a reduction in the number of total coliforms and the number of thermotolerant coliforms in the litter of broilers fed the diets containing the evaluated additives. The greatest reduction was observed in the litter of broilers diets containing enzymes $(0.68 \times 107$ MPN/100 mL) and enzymes combined with DFM 
Praes MFFM, Lucas Junior J, Duarte KF, Sorbara JOB, Matos Junior JB, Sgavioli S, Domingues CHF, Garcia RG, Hermes R

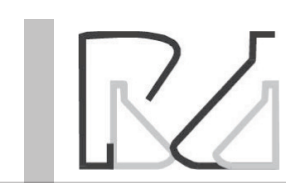

(0.14x107 MPN/100 mL), followed by the litter of birds that received the diet with DFM (11.00x107 MPN/100 $\mathrm{mL}$ ). These results demonstrate that the evaluated additives improved litter hygienic quality, as shown by the microbial loads obtained when compared with control treatment litter (11.80×107 MPN/100 mL) (Table 4). According to Sobestiansky (2002), disease incidence is directly related with environmental contamination in intensive animal production. In industrial broiler production in particular, there is a high daily rate of excreta deposition on the litter, in addition of feed and water, which may increase the load of pathogenic microorganisms. According to Kiehl (2004), the profile of the microbial population in the litter, in terms of number and species, depends on the litter substrate conditions that may favor or not their replication.

Table 04 - Number of total and thermotolerant coliforms (MPN/100 mL) in the litter of broilers reared up to 42 days of age and fed diets containing an enzyme blend and direct-fed microbes (DFM).

\begin{tabular}{lcc}
\hline \multirow{2}{*}{ Treatments* $^{*}$} & \multicolumn{2}{c}{ Characteristics } \\
\cline { 2 - 3 } & $\begin{array}{c}\text { Total Coliforms } \\
\text { (MPN/100ml) }\end{array}$ & $\begin{array}{c}\text { Thermotolerant Coliforms } \\
\text { (MPN/100ml) }\end{array}$ \\
\hline NC & $11.00 \times 10^{7} \mathrm{~A}$ & $11.80 \times 10^{7} \mathrm{~A}$ \\
DFM & $7.80 \times 10^{7} \mathrm{~B}$ & $7.80 \times 10^{7} \mathrm{~B}$ \\
ENZ & $0.68 \times 10^{7} \mathrm{C}$ & $0.68 \times 10^{7} \mathrm{C}$ \\
DFM+E & $0.14 \times 10^{7} \mathrm{C}$ & $0.14 \times 10^{7} \mathrm{C}$ \\
F Values & 3.88 & 3.88 \\
P Values & $0.042 * *$ & $0.042 * *$ \\
CV 1 (\%) & 8.22 & 8.22 \\
\hline
\end{tabular}

${ }^{1}$ coefficient of variation; ${ }^{*} \mathrm{NC}$ : negative control; DFM: NC +500 ppm of direct-fed microbial product (DFM) containing Bacillus subtilis and Bacillus licheniformis; ENZ: diet formulated with an enzyme blend (20 ppm phytase enzyme, 200 ppm protease and 200 ppm de xylanase); DFM+E: ENZ + DFM. A-C: means followed by different letters (columns) significantly differ $(p \leq 0.05)$ by Tukey's test.

The inclusion of additives in broiler diets may create an unfavorable environment microbial growth, due to the competition for food in the litter substrate. There
Reduced Nutrient Excretion and Environmental Microbial Load with the Addition of a Combination of Enzymes and Direct-Fed Microbials to the Diet of Broiler Chickens

are few studies on the influence of the inclusion of additives in the diet of broiler chickens on poultry litter. However, Brito \& Tagliari (2007) found that adding Bacillus subtilis and protease enzymes directly to the poultry litter reduced $E$. coli counts as of 24 hours in contact, and also significantly prevented the occurrence of cellulitis in broilers exposed to pathogenic strains of E. coli.

There were significant effects of the dietary treatments $(p<0.05)$ on litter $P$ and $N$ contents. The litter of broilers fed DFM the highest $\mathrm{N}$ content, followed by the litter of those enzymes and enzymes combined with DFM, where as the lowest $\mathrm{N}$ content was observed in the litter of the control birds (Table 5). This was not expected, because when the diet contains additives, especially exogenous enzymes, bird utilize the nutrients present in feed ingredients more effectively, thereby reducing their excretion in the environment. According to Costa et al. (2004), exogenous enzymes may reduce the excretion of pollutants, such as phosphorous and nitrogen, but their excretion levels depend on diet formulation. This results maybe explained by the action of Bacillus spp, which promotes the degradation of litter organic matter, releasing bound $\mathrm{N}$ from substrates, and consequently available $\mathrm{N}$ in the litter. However, other parameters, such $\mathrm{pH}$, ammoniacal nitrogen and its volatilization, should be analyzed a more detailed evaluation of $\mathrm{N}$ litter content.

The broilers fed the diets containing enzymes and enzymes + DFM presented the lowest $P$ deposition level in the litter. This may have occurred due to the presence of phytase in the enzyme blend added to the diets, which enabled greater $P$ absorption as a result of total or partial hydrolysis of the phytic acid present in the plant feedstuffs. Banks et al. (2004), studying the

Table 05 - Chemical composition (N, P and K) of the litter offed diets containing an enzyme blend and direct-fed microbes (DFM).

\begin{tabular}{|c|c|c|c|c|c|c|}
\hline \multirow{3}{*}{ Treatments* } & \multicolumn{6}{|c|}{ Chemical Composition } \\
\hline & \multicolumn{3}{|c|}{$(\%)$} & \multicolumn{3}{|c|}{ kg/kg of litter (DM) } \\
\hline & $\mathrm{N}$ & $P$ & K & $\mathrm{N}$ & $P$ & K \\
\hline NC & $2.64 \mathrm{D}$ & $2.47 \mathrm{~A}$ & 3.18 & $0.026 \mathrm{D}$ & $0.025 \mathrm{~A}$ & 0.031 \\
\hline DFM & $2.99 \mathrm{~A}$ & $2.56 \mathrm{~A}$ & 3.20 & $0.030 \mathrm{~A}$ & $0.026 \mathrm{~A}$ & 0.032 \\
\hline ENZ & $2.73 C$ & $1.90 \mathrm{~B}$ & 3.16 & $0.027 \mathrm{C}$ & $0.019 \mathrm{~B}$ & 0.033 \\
\hline $\mathrm{DFM}+\mathrm{E}$ & $2.90 \mathrm{~B}$ & $1.87 \mathrm{~B}$ & 3.07 & $0.029 \mathrm{~B}$ & 0.018 B & 0.032 \\
\hline F Values & 72.4 & 130.07 & 0.72 & 72.43 & 121.90 & 0.72 \\
\hline P Values & $<0.0001^{* *}$ & $<0.0001 * *$ & $0.5456^{\mathrm{NS}}$ & $<0.0001^{* *}$ & $<0.0001$ ** & $0.5456^{\mathrm{NS}}$ \\
\hline $\mathrm{CV}^{1}(\%)$ & 1.96 & 4.41 & 5.27 & 1.96 & 4.49 & 5.52 \\
\hline
\end{tabular}

${ }^{1}$ coefficient of variation; ${ }^{*} \mathrm{NC}$ : negative control; DFM: NC + 500 ppm of direct-fed microbial product (DFM) containing Bacillus subtilis and Bacillus licheniformis; ENZ: diet formulated with an enzyme blend (20 ppm phytase enzyme, 200 ppm protease and 200 ppm de xylanase); DFM+E: ENZ + DFM. ${ }^{* *} p \geq 0.05$. Ns not significant. A-B: means followed by different letters (columns) significantly differ ( $\mathrm{p} \leq 0.05)$ by Tukey's test. 
Praes MFFM, Lucas Junior J, Duarte KF, Sorbara JOB, Matos Junior JB, Sgavioli S, Domingues CHF, Garcia RG, Hermes R
Reduced Nutrient Excretion and Environmental Microbial Load with the Addition of a Combination of Enzymes and Direct-Fed Microbials to the Diet of Broiler Chickens

\section{CONCLUSION}

The addition of exogenous enzymes and their combination with a DFM product based on Bacillus spp. to the diet of broiler chickens does not change the amount of waste output and offers environmental benefits by reducing the microbial load and the amounts of phosphorus and insoluble fiber in the litter. Therefore, the litter can be a source of income as a source of organic fertilizer to be applied on the farm or to market.

\section{REFERENCES}

Almeida MAC. Fatores que afetam a umidade da cama. Avicultura Industrial $1986 ; 76: 16-18$.

APHA - American Public Health Association. Standard methods for examination of water and wastewater. 21th ed. Washington; 2005.

AOAC - Association of Official Analytical Chemists International. Official methods of analysis. 18th ed. Gaithersburg; 2005.

Avila VS, Mazzuco H, Fiqgueiredo, EAP. Cama de aviário: materiais, reutilização, uso como alimento e fertilizante [circular técnica 16]. Concórdia: EMBRAPA-CNPSA; 1992.

Banks K M, Thompson KL, Jaynes P, Applegate TJ. The effect of copper on the efficacy of phytase, growth, and phosphorus retention in broiler chicks. Poultry Science 2004;83(8):1335-1341.

Brito BG, Tagliari KC. Efeito da utilização de Impacto na ocorrência de celulite em frangos de corte. Hora Veterinária 2007;26:13-20.

Chang MH, Chen TC. Reduction of broiler house malodor by direct feeding of a Lactobacilli containing probiotic. International Journal of Poultry Science $2003 ; 2: 313-317$.

Costa FGP, Clementino RH, Jacome IMTD, Nascimento GAJ, Pereira WE. Utilização de um complexo multienzimático em dietas de frangos de corte. Ciência Animal Brasileira 2004;5(2):63-71.

Kiehl EJ. Manual de compostagem. 4th ed. Piracicaba: Editora Degaspari. 2004.

Ludke MCMM, Lope J, Ludke JV. Fitase em dietas para suínos em crescimento: impacto ambiental. Ciência Rural 2002;32:97-102. in literature on litter composition as affected by diet formulation, and therefore, further studies are needed.

Table 06 - Fiber composition of the litter offed diets containing an enzyme blend and direct-fed microbes (DFM).

\begin{tabular}{|c|c|c|c|c|c|c|}
\hline \multirow{3}{*}{ Treatments* } & \multicolumn{6}{|c|}{ Fiber Fraction } \\
\hline & \multicolumn{3}{|c|}{ (\%) } & \multicolumn{3}{|c|}{ kg/kg litter(DM) } \\
\hline & NDF & ADF & Lignin & NDF & ADF & Lignin \\
\hline NC & $57.51 \mathrm{~A}$ & $33.06 \mathrm{~A}$ & $8.8 \mathrm{C}$ & 0.46 & $0.33 \mathrm{~A}$ & $0.19 \mathrm{~B}$ \\
\hline DFM & $54.95 \mathrm{~B}$ & $30.41 \mathrm{~B}$ & $9.38 \mathrm{~B}$ & 0.44 & $0.30 \mathrm{~B}$ & $0.21 A B$ \\
\hline ENZ & 55.46 B & $27.18 \mathrm{C}$ & $9.81 \mathrm{~A}$ & 0.45 & $0.27 C$ & $0.23 \mathrm{~A}$ \\
\hline $\mathrm{DFM}+\mathrm{E}$ & $52.62 \mathrm{C}$ & $27.01 \mathrm{C}$ & $7.10 \mathrm{D}$ & 0.46 & $0.28 \mathrm{C}$ & $0.16 \mathrm{C}$ \\
\hline F Values & 109.62 & 197.23 & 171.10 & 0.22 & 197.23 & 27.50 \\
\hline P Values & $<0.0001 * *$ & $<0.0001 * *$ & $<0.0001 * *$ & $0.88^{\mathrm{NS}}$ & $<0.0001 * *$ & $<0.0001 * *$ \\
\hline $\mathrm{CV}^{1}(\%)$ & 1.04 & 2.10 & 3.10 & 7.89 & 2.09 & 8.09 \\
\hline
\end{tabular}

${ }^{1}$ coefficient of variation; ${ }^{*} \mathrm{NC}$ : negative control; DFM: NC + 500 ppm of direct-fed microbial product (DFM) containing Bacillus subtilis and Bacillus licheniformis; ENZ: diet formulated with an enzyme blend (20 ppm phytase enzyme, 200 ppm protease and 200 ppm de xylanase); DFM+E: ENZ + DFM. ${ }^{* *} p \geq 0.05$. ${ }^{\text {Ns }}$ not significant. A-B: means followed by different letters (columns) significantly differ ( $\mathrm{p} \leq 0.05)$ by Tukey's test. 
Praes MFFM, Lucas Junior J, Duarte KF,

Sorbara JOB, Matos Junior JB, Sgavioli S, Domingues CHF, Garcia RG, Hermes R

Maguire RO, Dou Z, Sims JT, Brake J, Joern BC. Dietary strategies for reduced phosphorus excretion and improved water quality. Journal of Environmental 2005;34:2093-2103.

Malavolta E. Micronutrientes: uma visão geral. In: Ferreira ME, Cruz MC. Micronutrientes na agricultura. Piracicaba: POTAFOS / CNPq; 1989. p.1-33.

Miele A, Milan PA. Composição mineral de cama de aviário de frangos de corte e sua utilização na adubação de vinhedos. Pesquisa Agropecuária Brasileira 1983;18:729-733.

Pinheiro CC, Rego JCC, Ramos TA, Silva BKR, Warpechowski MB. Digestibilidade dos nutrientes e desempenho de frangos de corte consumindo dietas formuladas com diferentes níveis de fibra e suplementadas com enzimas exógenas. Ciência Animal Brasileira 2008;9:984-996

Rondon EO. Technologies to mitigate the environmental impact of broiler production. Revista Brasileira de Zootecnia 2008;37:239-252.

Rostagno HS, Albino LFT, Donzele JL, Gomes PC, Oliveira RF, Lopes DC, et al. Tabelas brasileiras para aves e suínos: composição de alimentos e exigências nutricionais. 3rd ed. Viçosa: Universidade Federal de Viçosa; 2011.

Santos II. Efeito de probiótico, óleos essenciais e enzimas em parâmetros produtivos e sanitários de frango de corte [tese]. Porto Alegre (RS): Faculdade de Agronomia, Universidade Federal do Rio Grande do Sul; 2010.
Reduced Nutrient Excretion and Environmental Microbial Load with the Addition of a Combination of Enzymes and Direct-Fed Microbials to the Diet of Broiler Chickens

Santos TMB, Lucas JR. J. Utilização de resíduos da avicultura de corte para a produção de energia. Anais do $5^{\circ}$ Congresso Internacional de Zootecnia; 2003; Uberaba (MG): ABZ/FAZU/ABCZ; 2003. p.131-141.

Santos TMB. Caracterização química, microbiológica e potencial de produção de biogás a partir de três tipos de cama, considerando dois ciclos de criação de frangos de corte [dissertação]. Jaboticabal (SP): Faculdade de Ciências Agrárias e Veterinária, Universidade Estadual Paulista; 1997.

SAS Institute. SAS proprietary software release 9.2. Cary: SAS Institute; 2002.

Silva DJ, Queiroz AC. Análise de alimentos: métodos químicos e biológicos. 3rd ed. Viçosa: Editora Universitária; 2006

Sobestiansky J. Sistema intensivo de produção de suínos - programa de biossegurança. Goiânia: Art 3; 2002.

Strehler A, Sutzle W. Biomass residues. In: Hall DO. Biomass: regenerable energy. Washington: Island Press; 1987

Torres DM. Valor nutricional de farelos de arroz suplementados com fitase, determinado por diferentes metodologias com aves [tese]. Lavras (MG): Universidade Federal de Lavras, Lavras; 2003.

União Brasileira de Avicultura. Relatório anual. Brasília: UBA; 2014 
